\title{
ANALISIS KEBUTUHAN SISTEM PENGELOLAAN MICROTEACHING DENGAN SIKLUS PENETAPAN, PELAKSANAAN, EVALUASI, PENGENDALIAN DAN PENINGKATAN (PPEPP) DALAM MENINGKATKAN KETERAMPILAN MENGAJAR CALON GURU INSTITUT PENDIDIKAN TAPANULI SELATAN
}

\author{
Oleh : \\ Armansyah Lubis ${ }^{\text {1) }}$;Hanafi' ${ }^{2)}$; Rabiyatul Adawiyah Siregar ${ }^{3)}$ \\ ${ }^{1,2}$ Dosen Program Studi Pendidikan Ekonomi, Institut Pendidikan Tapanuli Selatan \\ ${ }^{3}$ Dosen Program Studi Pendidikan Kimia, Institut Pendidikan Tapanuli Selatan
}

\begin{abstract}
Abstrak
Penelitian ini bertujuan untuk mengetahui gambaran kemampuan mahasiswa IPTS dalam mengaplikasikan keterampilan mengajar mengadakan variasi dalam kegiatan PPL. Metode penelitian yang digunakan adalah deskriptif. Populasi dalam penelitian ini adalah seluruh mahasiswa PPL NPM 2015 tahun ajaran 2018/2019, sedangkan yang menjadi sampel penelitian berjumlah 103 orang. Hasil analisa data menunjukkan bahwa gambaran mahasiswa PPL mengaplikasikan keterampilan mengajar mengadakan variasi secara keseluruhan diperoleh nilai persentase 8,10\% kategori kurang. Kemampuan untuk variasi suara dengn persentase $43 \%$, pemusatan/perhatian dengan persentase $34 \%$, pemberian waktu atau kesenyapan dengan persentase $39 \%$, mengadakan kontak pandang dengan persentase $26 \%$, pada indikator gerakan badan/ mimik wajah dengan persentase $34 \%$ dan perubahan posisi dengan persentase $26 \%$. Berdasarkan Hasil analisis diatas dapat disimpulkan bahwa mahasisiwa PPL dalam keterampilan mengajar mengadakan variasi masih kategori kurang.
\end{abstract}

Kata kunci: Mahasiswa PPL, Keterampikan Mengajar, Mengadakan Variasi

\section{PENDAHULUAN}

Mata kuliah microteaching juga merupakan sebagai tempat latihan mengajar seorang calon guru. Sebagai calon guru harus mampu menguasai semua keterampilanketerampilan mengajar. Keterampilan ini di pelajari atau diberikan pada saat mata kuliah microteaching/latihan mengajar sebagai bekal dalam pelaksanaan Praktek Pengalaman Lapangan (PPL) disuatu sekolah di LPTK.

"Pengalaman pembelajaran microteaching memberikan manfaat bagi calon guru yaitumemperlihatkan calon guru dalam mengajar yang sebenarnya, membantu calon gurumelihat pentingnya pelaksanaan, pengambilan keputusan, pelaksanaan instruksi, memungkinkan calon guru untuk mengembangkan dan meningkatkan keterampilanmereka dan membantu calon guru dalam membangun kepercayaan diri mereka untukmengajar (Peker, 2009)".

Mutu lulusan berkaitan dengan ciri khas yang ditentukan oleh perguruan tinggi serta menunjukkan kesiapan lulusan untuk terjun danberkarya langsung di masyarakat dan duniakerja sebagaimana diharapkan oleh pelanggandan stake holders. Berdasarkan hasil penelitian Siram (2015: 54) menyatakan "perguruan tinggi agar memberikan perhatian terhadap manajemen penjaminan mutululusan".

Hasil wawancara dengan beberapa mahasiswa IPTS yang melaksanakan kegiatan PPL pada tanggal 20 Juli 2018 ditemukan bahwa mahasiswa PPL di sekolah mengalami kesulitan dalam mengaplikasikan keterampilan mengajar di lapangan. Masalah yang dihadapi mahasiswa misalnya penyusunan RPP, kurangmenguasai model pembelajaran, dan pengalaman mahasiswa dalam mengajar masih belum ada. Hal ini didukung dari hasil penelitian yang dilakukan R. Siregar (2019) yang menyatakan bahwa "gambaran mahasisiwa PPL IPTS dalam mengaplikasikan keterampilan mengajar mengadakan variasi, diperoleh nilai persentase secara keseluruhan sebesar 21,7\% pada kategori "kurang".

$$
\text { Berdasarkanpermasalahan }
$$

yang telahdiuraikan di atas, adabeberapahal yang perlu dilatih terutama dalam penyusunan RPP, penggunaan model pembelajaran, melatihsiswa agar memiliki kepercayaan diri dalam mengajar. Salah satu mata kuliah pendukung dan merupakan prasyarat bagi mahasiswa yang akan mengikuti kegiatanPPL. Dengan demikian, pada saat mahasiswa melaksanakan PPL, mahasiswa tersebutsudah memiliki keterampilan dasar mengajar karena keterampilan tersebut sudah pernahdilatihkan dalam pembelajaran mikro. Di samping itu, mahasiswa dapat berlatihketerampilan mengajar yang lebih kompleks dalam melaksanakan PPL.

Apabila masalah ini terus dibiarkan, maka akan mengakibatkan siswa mengalami kebosanan dan kejenuhan dalam proses pembelajaran dan akan mengalami ketertinggalan dalam mencapai prestasi yang baik dan tujuan pembelajaran tidak akan tercapai.

Beberapa upaya telah dilakukan oleh tim dosen microteaching antara lain dengan menambahfrekwensi latihan simulasi, menyediakan 
sarana dan prasarana, seperti: perpustakaan, laboratorium microteaching yang dapat membantu para calon guru untuk mengaplikasikan beberapa keterampialan guru atau latihan dalam mengajar dan batuan dari buku-buku tentang strategi belajar mengajar dari perpustakaan yang bisa sebagai acuan para mahasiswa calon guru dalam mengaplikasikannya pada pelaksanaan PPL dan para mahasisiwa juga di berikan waktu pembekalan sebelum para mahasisiwa terjun ke lapangan.

Berbagai model pembelajaran telah diterapkan dalam perkuliahan microteaching, antara lain modelobservasi dan simulasi, model learner centered(Kartikowati, 2014,Killic, 2010), model kontekstual(Elmy, 2013), dilandasi teori microteaching (Allen \&Brown, 1975), Personal Model of Teaching danSocial Model of Teaching (Weil dan Joyce, 1996), dan teori contextual teaching and learning (Johnson)dan model-model pembelajaran lain yang berorientasipada pengalaman dan latihan mengajar untuk mencapai tujuan perkuliahaan microteaching.

Tujuan microteaching bagi calon guru adalah: 1) memberi pengalaman mengajar yang nyatadan latihan sejumlah keterampilan dasar mengajar, 2)calon guru dapat mengembangkan keterampilanmengajarnya sebelum mereke terjun ke lapangan, 3)memberikan kemungkinan bagi calon guru untukmendapatkan bermacam-macam keterampilan dasarmengajar. berdasarkan tujuan ini diharapkan penggunaan sistem pengelolaan mata kuliah microteaching harus sistematis dan lebih bermutu. Sehingga, perlukiranya mengadopsi siklus yang digunakan dalam SPMI yaitu tahap PPEPP (Perencanaan, Pelaksanaan, Evaluasi, Pendendalian dan Peningkatan) agar sistem pengelolaan mata kuliah microtgeaching lebih bermutu. Adapun solusi yang peneliti tawarkan dalam mengatasi permasalahan di atas ialah menganalisis kebutuhan sistem pengelolaan microteaching dengan siklus PPEPP dalam meningkatkan keterampilan mengajar guru.

Penelitian ini bertujuan mengetahui kebutuhan sistem pengelolaan microteaching dengan menggunakan siklus PPEPP (Perencanaan, Pelaksanaan, Evaluasi, Pendendalian dan Peningkatan) agar sistem pengelolaan mata kuliah microtgeaching lebih bermutu dan dapat meningkatkan keterampilan mengajar mahasiswa IPTS.

\section{METODOLOGI PENELITIAN}

Penelitian ini diaksanakan di IPTS. Adapun alasan peneliti menjadikan kampus IPTS sebagai lokasi penelitian mengenai masalah yang akan diteliti, karena peneliti menemukan sesuatu masalah yang berhubungan dengan kesulitan mahasiswa dalam mengaplikasikan keterampilan mengajar guru dalam mengadakan variasi dalam waktu melaksanakan PPL.
Jenis penelitian yang digunakan adalah penelitian deskriptif. Sedangkan, sampel dalam penelitian ini adalah mahasiswa yang telah PPL dengan NPM 2015 IPTS tahun ajaran 2018/2019 yang berjumlah174 orang.

Data ini di dapat dari responden dengan mengunakan angket secara tertutup yang telah disediakan. Untuk memperoleh informasi data tahap analisis kebutuhan mengenai sistem pengelolan microteaching dengan menggunakan siklus PPEPP. Adapun anget yang digunakan mengenai analisis RPS mata kuliah microteaching, analisis pelaksanaan kegiatan microteaching dan analisis keterampilan mengajar calon guru. Setealah data terkumpul langkah selanjutnya dianalisis untuk memperoleh deskripsi data dalam bentuk nilai rata-rata.

\section{HASIL PENELITIAN DAN \\ PEMBAHASAN}

Komponen standar dalam lingkup standar mutu pendidikan harus diusahakan untuk mencapai mutu yang diinginakan baik stakeholder internal maupun eksternal". Peningkatan mutu penyelenggaraan pendidikan di perguruan tinggi dititik beratkan pada penciptaan proses pembelajaran yang aktif, efektif, efisien, dan kondusifagar dapat memberikan bekal kemampuan akademis dan profesional kepada mahasiswa, sehingga lulusan

yang dihasilkan siap bersaing di pasar global (Sastrawan, 2015: 1)merupakan bagian dari standar proses pembelajaran.

Penggunaan siklus PPEPP pada mata kuliah microteaching bertujuan agar lulusan calon guru lebih bermutu. Upaya pencapaian mutu yang diharapkan tentu bahwasannya tidak terlepas dari dukungan kepemimpinan serta proses manajerial yang baik untuk meningkatkan etos kerja civitas akademika demi terciptanya lingkungan akademik yang kondusif. "Kemampuan manajerial ialah faktor penting dan strategis dalam kerangka peningkatan mutu dan kemajuan perguruan tinggi yang dipimpinnya. Pemimpin perguruan tinggi yang bertanggung jawab harus menyadari bahwa perkembangan dan peningkatan mutu pengelolaan organisasi menjadi sangat penting.Karena itu, untuk dapat mengungkap mengenai kinerja, hasil dan dampak perguruan tinggi secara periodik dan teratur, harus dilakukan evaluasi sebagai bagian dari pola managemen perguruan tinggi (Ernawati dan Hilwati, 200: 40)".SPMI harus menjamin bahwa tujuan utama rencana anggaran pendapatan dan belanjaialah untuk mengembangkan perguruan tinggi melalui implementasi tri dharma perguruan tinggi (Fitrah, 2018).

Tahap ini digunakan untuk memperoleh informasi mengenai kebutuhan atau masalah yang melatarbelakangi dikembangkannya desain sistem pembelajaran microteaching berbasisi siklus PPEPP untuk meningkatkan keterampilan mengajar 
calon guru (mahasiswa). Adapun tahapan analisis dalam penelitian ini meliputi: a) analisis Rencana Pembelajaran Semester (RPS) mata kuliah microteaching; b) analisis pelaksanaan microteaching; c) analisis keterampilan mengajar calon guru.

a. Analisis Rencana Pembelajaran Semester (RPS) mata kuliah microteaching

Hasil analisis RPS yang dibuat oleh Dosen IPTS secara keseluruhan diperoleh nilai rata-rata 70 dikategori baik. Data selengkapnya disajikan pada Tabel 4.1.

Tabel 1. Deskripsi Evaluasi RPS Mata Kuliah Microteaching IPTS

\begin{tabular}{|c|c|c|c|}
\hline No & Aspek yang dinilai & Nilai & Kategori \\
\hline 1. & $\begin{array}{l}\text { Kelengkapan unsur } \\
\text { RPS }\end{array}$ & 100 & $\begin{array}{l}\text { Sangat } \\
\text { Baik }\end{array}$ \\
\hline 2. & \begin{tabular}{lr}
\multicolumn{2}{l}{ Keterkaitan } \\
capaian pembelajaran \\
lulusan prodi & (CPL) \\
dengan & capaian \\
pembelajaran & mata \\
kuliah (CPMK) & \\
\end{tabular} & 100 & $\begin{array}{l}\text { Sangat } \\
\text { Baik }\end{array}$ \\
\hline 3. & $\begin{array}{lr}\text { Rumusan } & \text { kemampuan } \\
\text { dalam } & \text { CPMK } \\
\text { menggunakan rata } \\
\text { kerja } \quad \text { operasional } \\
\text { untuk memudahkan } \\
\text { proses penilaian }\end{array}$ & 100 & $\begin{array}{l}\text { Sangat } \\
\text { Baik }\end{array}$ \\
\hline 4. & $\begin{array}{l}\text { Rumusan CPMK hars } \\
\text { berorientasi kepada } \\
\text { mahasiswa }\end{array}$ & 100 & $\begin{array}{l}\text { Sangat } \\
\text { Baik }\end{array}$ \\
\hline 5. & $\begin{array}{lr}\text { Ketersediaan } & \text { dan } \\
\text { kebaruan } & \text { sumber } \\
\text { belajar } & \\
\end{array}$ & 33 & Gagal \\
\hline 6. & $\begin{array}{ll}\text { Minimal ada } & \text { tiga } \\
\text { strategi/model/metode } \\
\text { pembalajaran } & \text { yang } \\
\text { berbeda } & \text { yang } \\
\text { digunakan } & \\
\end{array}$ & 78 & Baik \\
\hline 7. & $\begin{array}{l}\text { Ada usaha untuk } \\
\text { mengintegrasikan hasil } \\
\text { penelitian dosen dalam } \\
\text { RPS (sumber belajar } \\
\text { dari hasil penelitian) }\end{array}$ & 33 & Gagal \\
\hline 8. & $\begin{array}{l}\text { Ada usaha untuk } \\
\text { mengintegrasikan hasil } \\
\text { PKM dosen dalam } \\
\text { RPS (sumber belajar } \\
\text { dari hasil PKM) }\end{array}$ & 33 & Gagal \\
\hline 9. & $\begin{array}{lr}\text { Evaluasi } & \text { pembelajaran } \\
\text { yang } & \text { dirancang } \\
\text { meliputi: } & \text { teknik, } \\
\text { instrumen } & \text { dan } \\
\text { pembobotan } & \\
\end{array}$ & 56 & Kurang \\
\hline 10. & $\begin{array}{l}\text { Adanya tugas dalam } \\
\text { bentuk individu dan } \\
\text { kelompok }\end{array}$ & 67 & Cukup \\
\hline
\end{tabular}

Berdasarkan Tabel 1. di atas pada aspek pertama tentang kelengkapan unsur RPS sudah kategori sangat baik. Hal ini menunjukkan bahwa seluruh dosen yang mengampu mata kuliah microteaching sudah membuat RPS sesuai format yang telah ditetapkan oleh IPTS.

Aspek kedua menunjukkan bahwa dosen pengampu mata kuliah microetaching dalam merumuskan CPL Program Studi (CPL) telah menghubungkan dengan CPMK akan tetapi masih ditemukan beberapa dosen yang belum menuliskan Capaian Pembelajaran Lulusan (CPL) dan CPMK pada RPS.

Aspek ketiga dosen telah merumuskan kemampuan dalam CPMK menggunakan kata kerja spesifik dan operasional untuk memudahkan proses penilaian, yakni dapat diidentifikasi atau dibuktikan dengan konsisten melalui alat penilaian. Oleh karena itu dalam merumuskan CPMK harus menggunakan kata kerja operasional sudah kategori sangat baik, akan tetapi masih ada juga dosen pada komponen kemampuan akhir yang diharapkan, masih ada dosen yang tidak menguraikan secara jelas hanya berupa pernyataan "mampu menjelaskan, mampu menjabarkan”. Kemampuan akhir yang diharapkan berisi kemampuan yang diperoleh mahasiswa setiap pertemuan sesuai dengan bahan kajian dan materi yang disampaikan.

Pada aspek ke-empat tidak berbeda dengan aspek 1 sampai dengan 3 dengan kategori sangat baik. Rumusan CPMK yang telah dimuat dalam RPS telah berorientasi kepada mahasiswa atau peserta didik. Dalam perumusan CPMK, mempertimbangkan tiga hal berikut: a) CPMK merinci suatu tindakan/kegiatan yang dilakukan oleh mahasiswa yang dapat diamati; b) CPMK merinci suatu tindakan/kegiatan yang dilakukan oleh mahasiswa yang dapat diukur; c) CPMK merinci suatu tindakan/kegiatan yang dilakukan oleh mahasiswa dan bukan oleh dosen.

Aspek kelima tentang sumber belajar yang digunakan pada mata kuliah microteaching. Hasil analisis yang diperoleh kategori gagal. Hal ini disebabkan sumber belajar yang digunakan kurang memadai, baik secara cetak maupun digital, sesuai dengan topik pembelajaran MK yang mutakhir sesuai dengan karakteristik mata kuliah. Seharusnya, dosen menyediakan sumber belajar dalam bentuk buku, internet, video dan lain-lain agar dapat pemahaman siswa pada materi microteaching yang diajarkan.

Aspek ke enam mengenai penggunaan strategi/model/metode pembalajaran berada pada ketgori kurang. Pada umumnya, metode pembelajaran dosen masih monoton, sebagian besar dosen menggunakan metode pembelajaran yang monoton (diskusi dan presentase/praktek). Pelaksanaan perkuliahaan microteaching dapat disimpulkan bahwa dosen secara umum menggunakan dua strategi/model/metode pembelajaran yang berbeda. 
Aspek ke tujuh dan kedelapan tentang pengintegrasikan hasil penelitian dosen dan PKM dalam RPS (sumber belajar dari hasil penelitian dan kegiatan PKM). Hasil analisis yang diperoleh kedua aspek ini pada kategor gagal. Dapatdisimpulkan bahwa RPS pada mata kuliah microteaching hasil kegiatan penelitian dan PKM tidak diintegrasikan sebagai sumber belajar.

Aspek kesembilan tentang penggunaan evaluasi pembelajaran yang dirancang tidak mencakup teknik dan instrumen penilaian, dan tidak mempertimbangkan pembobotan, sehingga berada pada kategori kurang. Sedangkan pada aspek pemberian tugas mahasiswa hanya dalam satu bentuk dengan kategori cukup.

b. Analisis Pelaksanaan Microteaching

Hasil data analisis pelaksanaan kegiatan microteaching yang selama ini digunakan di Institut Pendidikan Tapanuli Selatan dalam penelitian ini dengan menggunakan instrumen angket. Angket yang disebarkan merupakan jenis angket tertutup yang diberikan kepada mahasiswa yang telah melaksanakan perkuliahaan microteaching. Hasil analisis ini bertujuan untuk memperoleh informasi sebagai bahan dasar desain sistem pengelolaan microteaching dengan siklus Penetapan, Pelaksanaan, Evaluasi, Pengendalian dan Peningkatan (PPEPP) dalam meningkatkan keterampilan mengajar calon guru IPTS.

Aspek yang diamati dari pelaksanaan kegiatan perkuliahaan microteaching telah dilaksanakan sebelumnya meliputi: 1) materi microteaching; 2) metode microteaching; 3) pelaksanaan microteaching; 4) evaluasi microteaching. Deskripsi data hasil analisis pelaksanaan microteaching dapat dilihat pada Tabel 2.

Tabel.2. Deskripsi Hasil Analisis Pelaksanaan Microteaching

\begin{tabular}{|c|l|c|c|}
\hline NO & \multicolumn{1}{|c|}{ Indikator } & Nilai & Kategori \\
\hline 1. & $\begin{array}{l}\text { Materi } \\
\text { microteaching }\end{array}$ & 69 & Cukup \\
\hline 2. & $\begin{array}{l}\text { Metode } \\
\text { microteaching }\end{array}$ & 67 & Cukup \\
\hline 3. & $\begin{array}{l}\text { Pelaksanaan } \\
\text { microteaching }\end{array}$ & 63 & Cukup \\
\hline 4. & $\begin{array}{l}\text { Evaluasi } \\
\text { microteaching }\end{array}$ & $\begin{array}{c}\text { Sangat } \\
\text { baik }\end{array}$ \\
\hline \multicolumn{2}{|c|}{ Nilai Rata-rata } & 72 & Baik \\
\hline \multicolumn{2}{|c|}{ Data tentang } & aspek pelaksanaan \\
\hline
\end{tabular}

perkuliahan microteaching diketahui bahwa dosen pengampu mata kuliah tidak menjelaskan prosedur penggunaan metode atau strategi dalam mengajar selama microteaching dan tidak menjelaskan penggunaan metode tertentu dalam praktek microteaching. Selanjutnya, dosen tidak terlalu memperhatikan strategi mengajar yang dilakukan oleh mahasiswa yang sedang mengajar. Pelaksanaan microteaching dilakukan setiap pertemuannya tanpa mengharuskan mahasiswa (praktikan) dengan menggunakan metode yang berbeda-beda. Pembelajaran Micro Teaching dipraktekkan tidak secara terisolasi/terpisah-pisah di setiap keteampilan mengajar. Hal ini berdampak sulit untuk mengetahui kemampuan praktikan untuk menggunakan keterampilan mengajar.

Evaluasi yang digunakan dosen pada pelaksanaan perkuliahaan microteaching kategori sangat baik. Dosen telah melibatkan teman sejawat mahasiswa untuk melakukan penilaian performance praktikan (calon guru) sebagai umpan balik untuk bahan koreksi bagi praktikan. Selama ini, penilaian dilakukan oleh dosen dan teman sejawat, akan tetapi mahasiswa yang berperan sebagai siswa tidak diberikan kesempatan memberikan penilaian kepada praktikan. Untuk itu dalam desain sistem pengelolaan microteaching yang dikembangkantim penilai yang berperan terdiri dari: dosen, teman sejawat (observer) dan mahasiswa yang berperan sebagai siswa.

c. Analisis Keterampilan Mengajar Calon Guru

Keterampilan dasar merupakan sebuah bentuk-bentuk perilaku yang bersifat mendasar yang harus dimiliki seorang guru sebagai modal awal untuk supaya dapat melaksanakan bentuk tugas-tugas pembelajaran dan mengelola lingkunganbelajarnya untuk selalu meningkatkan kualitas pembelajaran itu sendiri.

Menurut Usman (2007:74), ada "delapan keterampilan dasar mengajar guru, yaitu: (a) keterampilan bertanya, (b) keterampilan memberi penguatan, (c) keterampilan mengadakan variasi, (d) keterampilan dasar menjelaskan, (e) keterampilan untuk membuka dan menutup pelajaran, (f) keterampilanmemimpin diskusi kelompok kecil, (g) keterampilan mengajar kelompok dan perorangan, dan (h) juga keterampilan mengelola kelas". Seorang Guru yang profesional harus dapat menguasai kedelapan keterampilan dasar dalam mengajar guru tersebut agar bisa melaksanakann tugasnya dengan baik.

Data keterampilan mengajar mahasiswa diperoleh dengan menggunakan angket yang diisi oleh mahasiswa yang telah melaksanakan PPL di sekolah. Hasil penilaian keterampilan mengajar mahasiswa IPTS disajikan pada Tabel 3.

Tabel 3. Deskripsi Keterampilan Mengajar Mahasiswa IPTS

\begin{tabular}{|c|l|c|c|}
\hline NO & \multicolumn{1}{|c|}{ Indikator } & Nilai & Kategori \\
\hline 1. & $\begin{array}{l}\text { Keterampilan } \\
\text { membuka dan } \\
\text { menutup } \\
\text { pembelajaran }\end{array}$ & 82 & $\begin{array}{c}\text { Sangat } \\
\text { baik }\end{array}$ \\
\hline 2. & $\begin{array}{l}\text { Keterampilan } \\
\text { menjelaskan }\end{array}$ & 72 & Baik \\
\hline 3. & $\begin{array}{l}\text { Keterampilan } \\
\text { bertanya tingkat } \\
\text { dasar }\end{array}$ & 75 & Baik \\
\hline 4. & $\begin{array}{l}\text { Keterampilan } \\
\text { bertanya tindak } \\
\text { lanjut }\end{array}$ & 71 & Baik \\
\hline 5. & Keterampilan & 76 & Baik \\
\hline
\end{tabular}




\begin{tabular}{|c|l|c|c|}
\hline \hline & $\begin{array}{l}\text { mengadakan } \\
\text { variasi }\end{array}$ & & \\
\hline 6. & $\begin{array}{l}\text { Keterampilan } \\
\text { mengelola kelas }\end{array}$ & 74 & Baik \\
\hline 7. & $\begin{array}{l}\text { Keterampilan } \\
\text { membimbing } \\
\text { diskusi kecil }\end{array}$ & 82 & $\begin{array}{c}\text { Sangat } \\
\text { Baik }\end{array}$ \\
\hline 8. & $\begin{array}{l}\text { Keterampilan } \\
\text { mengajar } \\
\text { kelompok kecil } \\
\text { dan perorangan. }\end{array}$ & 70 & Baik \\
\hline & Nilai Rata-rata & 75 & Baik \\
\hline
\end{tabular}

Berdasarkan Tabel 3 di atas, keterampilan mengajar mahasiswa sudah kategori baik, akan tetapi masih perlu ditingkat kearah lebih baik lagi. Dari 8 (delapan) indikator yang diajukan yang paling rendah adalah keterampilan mengajar kelompok kecil dan perorangan, sedangkan indikator yang paling tinggi dikuasai oleh mahasiswa adalah keterampilan membuka dan menutup pelajaran, serta keterampilan membimbing diskusi kecil. Untuk itu perlu kiranya dilakukan perbaikan dalam perkuliahan microteaching, khusunya agar siswa memiliki keterampilan mengajar kelompok kecil dan perorangan dengan meningkatkan interaksi guru dengan siswa dengan menggunakan pemilihan metode mengajar yang dipraktekkan agar lebih bervariasi.

Hasil penelitian ini menunjukkan bahwa Penguasaan Keterampilan Mengajar mahasiswa IPTS dari segi Keterampilan membuka dan menutup pelajaran adalah sudah terampil. Kesimpulan ini didasarkan pada hasil analisiskecenderungan data yang menunjukkan kategori sangat baik. Hasil penelitian ini sesuai dengan kajianteori yang telah dipaparkan sebelumnya, yaitu bahwa keterampilan membukaPelajaran yang dimiliki oleh Mahasiswa akan menyebabkan seseorang tersebut akanlebih berhasil dalam mengajar, Hal ini karena bila mahasiswa memiliki keterampilanmembuka Pelajaran yang tinggi akan menimbulkan motivasi dan kemauan, sertaketertarikan dalam belajar pada siswa. Kemauan dan rasa ketertarikan untuk belajaryang besar serta ini lah yang akan menciptakan suasanan pembelajaran yang menyenangkan yang berimbas pada keberhasilan dalam kegiatan pembelajaran

Keterampilan membuka pelajaran; keterampilan yang sudah dikuasai mahasiswadalam membuka pelajaran adalah memberikan apersepsi dengan menggunakan pertanyaan-pertanyaan yang berkaitan dengan materi yang akan dipelajari dan memberikan gambaran kegiatan dan/atau cakupan materi pada pertemuan tersebut. Keterampilan yang belum dikuasai adalah mengkomunikasikan tujuan yang akan dicapai siswa. Hasil penelitian ini sesuai dengan kajian teori yang telah dipaparkan sebelumnya, yaitu bahwa Keterampilan Menutup Pelajaran akan mahasiswa akan dapat

menyimpulkan dan membual evaluasi ketercapaian kegiatan yang dilakukan untuk digunakan sebagai bahan perbaikan di kemudian hari. Dengan adanya kegiatan Menutup Pelajaran yang Terampil maka peserta didik akan dapat mengetahui kesimpulan berbagai materi yang telah diajarkan dan mengetahui materi selanjutnya yang akan diajarkan sehingga dapat melakukan persiapan untuk mengikuti kegiatan pembelajaran selanjutnya.

Keterampilan mahasiswa menjelaskan materi pelajaran cukup baik dalammengorientasikan dan memberikan motivasi kepada siswa pada waktu melakukan bahan apersepsi, kemudian penggunaan bahasa yang sederhana dan jelas serta kesesuaian susunan kalimat, memberikan contoh yang digunakan banyak, konkret dan tepat, selanjutnya sistematika penjelasan memberikan tekanan suara dan gambar, bervariasi dalam pennggunaan metode, dan mengadakan pertanyaan dan latihan sebagai balikan.

Keterampilan mahasiswa mengajukan pertanyaan ditunjukkan dengan baik, dapat memberikan arahan atas materi yang disampaikan kepada siswa dan dapat membuat siswa lebih aktif dalam proses pembelajaran sertamengetahui seberapa jauh pemahaman siswa mengenai materi pelajaran yang telah disampaikan.

Keterampilan mahasiswa dalam pemberian penguatan baik, hal ini dapat dilihat dariaktivitas guru (mahasiswa) merespon kegiatan siswa baik berupa kata-kata atau gerakan-gerakan juga menciptakan kehangatan serta kebermaknaan dalam berlangsungnya proses pembelajaran. Keterampilan mahasiswa dalam mengadakan variasi menurut guru pamong terkategori baik.

Hasil penelitian ini menunjukkan agar mahasiswa agar lebih menguasai materi pelajaran secara luas dan mendalam serta kholistik serta mahasiswa dalam menjelaskan pelajaran sebaiknya logis dan sitematik dengan memberikan contohcontoh yang didukung oleh berbagai variasi dan metode serta media pembelajaran. Selain itu, dosen saat mengajar di kelas lebih mengarahkan pada penekanan pembelajaran aktif sehingga terjadi pembelajaran interaktif yang kondusif antara pengajar dan pembelajar dengan tujuan agar mahasiswa mampu mengemukkan pendapat sehingga mahasiswa memiliki kemampuan keterampilan berbicara yang logis dan sistematis sekaligus mampu mengelola kelas.

Guru memiliki peran utama dalam pengelolaan pembelajaran. Idealnya,seorang guru harus memperhatikan aspek-aspek pengelolaan pembelajaran yang tercakup dalam perencanaaan, pengorganisasian, pelaksanaan dan penilaian hasil pembelajaran. Sutama (2011: 9-10) mengatakan bahwa "pengelolaan pembelajaran matematika mengutamakan peran aktif siswa, guru berperan sebagai perancang, fasilitator, dan pembimbing proses pembelajaran". 
Selama

berlangsungnyakegiatanpembelajaran, siswa dituntut untuk memadukanaktivitas fisik dan mental mereka untuk mencapaitujuan pembelajaran yang telah ditentukan. "Agarkegiatan pembelajaran dapat berlangsung denganaktif, inovatif, kreatif, dan menyenangkan perluadanya suatu perangkat pembelajaran serta modelpembelajaran yang sesuai yang mendukungterciptanya suasana pembelajaran tersebut (R. Siregar, 2019)”.

\section{KESIMPULAN}

Kepuasan stakeholders internal merupakan salah satu indikator keberhasilan mutu perguruan tinggi. Penerapan sistem penjaminan mutu internal di perguruan tinggi sangat penting dalam meningkatkan mutu, sehingga dapat menghasilkan lulusan yang sesuai dengan apa yang diharapkan stakeholder. SPMI dibuat sebagai dasar untuk mengendalikan pengelolaan pendidikan tinggi bermutu dengan standar Nasional dan memenuhi peraturan pemerintah Republik Indonesia.

Proses SPMI tidak terlepas dari kebijakan mutu, sasaran mutu penyelenggaraan pendidikan, serta seluruh dokumen mutu yang harus disosialisasikan kepada seluruh sivitas akademika dan pimpinan lembaga agar diimplementasikan secara optimal. Hasil penelitian dan pembahasan diperoleh simpulan sebagai berikut:

1. Aspek RPS microteaching IPTS yang telah dibuat dosen masih perlu dilengkapi misalnya, menuliskan Capaian Pembelajaran Lulusan (CPL) dan CPMK pada RPS, dosen menyediakan sumber belajar dalam bentuk buku, internet dan video, Pelaksanaan perkuliahaan microteaching dapat disimpulkan bahwa dosen secara umum menggunakan dua strategi/model/metode pembelajaran yang berbeda untuk itu agar lebih divariasikan lagi agar lebih sistematis mulai dari tahap perencanaan, pelaksanaan, evaluasi dan peningkatan keterampilan mengajar mahasiswa sebagai calon guru, serta bentuk evaluasi atau penilaian masih perlu diperbaiki dengan melibatkan mahasiswa sebagai observer, dosen dan mahasiswa sebagai siswa.

2. Aspek pelaksanaan microteaching selama ini dilaksanakan masih perlu diperbaiki anatara lain: Format penilaian RPP tidak disesuaikan dengan format penilaian ketika pelaksanaan Praktek Mengajar ke sekolah atau ketika pelaksanaan PPL. Pembelajaran Micro Teaching dipraktekkan tidak secara terisolasi/terpisah-pisah di setiap keterampilan mengajar. Hal ini berdampak sulit untuk mengetahui kemampuan praktikan untuk menggunakan keterampilan mengajar. Selama ini, penilaian dilakukan oleh dosen dan teman sejawat, akan tetapi mahasiswa yang berperan sebagai siswa tidak diberikan kesempatan memberikan penilaian kepada praktikan. Untuk itu dalam desain sistem pengelolaan microteaching yang dikembangkantim penilai yang berperan terdiri dari: dosen, teman sejawat (observer) dan mahasiswa yang berperan sebagai siswa.

\section{REFERENSI}

Elmy, M. 2013. Penerapan Microteaching Berbasis Pembelajaran PKn Kontekstual dalam Pembangunan Kompetensi Mengajar (Pedagogik) Mahasiswa (Studi Eksperimen Kuasi pada Mahasiswa Pkn Fkip Unlam Banjarmasin). Tesis.Tidak diterbitkan+journal+\&ie $=$ utf- $8 \&$ oe $=u t f-8$ diakses tanggal 20 April 2014.

Ernawati \& Hilwati. 2001. Pengembangan

Mutu Perguruan Tinggi Dengan

PolaManajemen Terpadu.Makalah

Lokakarya Asistensi Penyusunan

Statuta PTS di Lingkungan Kopertis

Wilayah IV, di Bandung, 25

November 2000 .

Fitrah. 2018. Urgensi Sistem Penjaminan Mutu InternalTerhadap Peningkatan Mutu Perguruan Tinggi. Jurnal Penjaminan Mutu Lembaga Penjaminan Mutu Institut Hindu Dharma Negeri Denpasar. Volume 4 Nomor 1 Pebruari 2018. ISSN : 25483110 (Online). http://ejournal.ihdn.ac.id/index.php/JPM.

Peker, M. 2009. The Use of Expanded Microteaching for Reducing Pre-Service Teachers'Teaching Anxiety about Mathematics. Journal of Scientific Research and Essay. 4 (9): 872-880.

Kilic, A. 2010. Learner-centered Microteaching in Teacher Education. International Journal ofInstruction, ISSN: 1694-609 x, Januari 2010. Vol 3 no. 1 (on line) http://www.google.com/search?q=mirotea ching

R. Siregar, A. Lubis, W. ., and D. Harahap, "WORKSHOP PENYUSUNAN RPPH K13 DENGAN PENDEKATAN SAINTIFIK UNTUK MENANAMKAN KAREKTER ANAK USIA DINI", JURNAL EDUCATION AND DEVELOPMENT, vol. 7, no. 2, p. 95,

R. Siregar, N. Sinaga, I. Hatchi, and A. Lubis, "ANALISIS

KESULITAN

MAHASISWA PRAKTEK PENGALAMAN LAPANGAN (PPL) INSTITUT PENDIDIKAN TAPANULI SELATAN (IPTS) DALAM MENGAPLIKASIKAN KETERAMPILAN MENGAJAR MENGADAKAN VARIASI", JURNAL EDUCATION AND DEVELOPMENT, vol. 7, no. 1, p. 95, Jan. 2019.Apr. 2019. 
Rusman. 2014.

Model-Model Pembelajaran.Jakarta: Rajawali press.

Sapendi. 2016. Manajemen Kepemimpinan Berbasis Mutu untuk Meningkatkan Daya Saing Perguruan Tinggi. Jurnal At-Turats Vol. 10 No. 2 (2016) 65 - 76 (online). https://www.google.com/search?safe=stric t\&ei=5hAgXZ2HA4b49QPk7q3QDQ\&q= jurnal+penerapan+siklus+ppepp+dalam+p embelajaran+mengadopsi+SPMI\&oq=jurn al+penerapan+siklus+ppepp+dalam+pemb elajaran+mengadopsi+SPMI\&gs_l=psyab.3..0i7118.47860.49080..49520...0.0..0.0 .0...........1..gws-wiz.JJCDIUENKiY.

Sastrawan, K. B. 2016. Profesionalisme Guru

Dalam Upaya Meningkatkan Mutu Pembelajaran. Jurnal Penjaminan Mutu,2(2), 65-73.

Sutama. 2011. Pengelolaan Pembelajaran Matematika, Berbasis Aptitude Treatment Interaction. Surakarta: Muhammadiyah University Press.

Usman Uzer.2007. Upaya Optimalisasi Kegiatan Belajar Mengajar. Bandung: Remaja Rosdakarya 